\title{
Activin-inhibitory action on lactotrophs is decreased in lactotroph hyperplasia
}

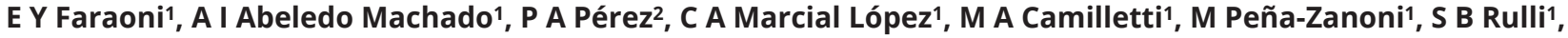 \\ S Gutiérrez² and G Díaz-Torga1
}

${ }^{1}$ Instituto de Biología y Medicina Experimental (IBYME), CONICET, Buenos Aires, Argentina

${ }^{2}$ Centro de Microscopia Electrónica, Instituto de Investigaciones en Ciencias de la Salud (INICSA-CONICET), Facultad de Ciencias Médicas, Universidad

Nacional de Córdoba, Córdoba, Argentina

Correspondence should be addressed to G Díaz-Torga: gdiaz@ibyme.conicet.gov.ar

\begin{abstract}
Among all the hormone-secreting pituitary tumours, prolactinomas are the most frequently found in the clinic. Since dopamine is the primary inhibitor of lactotroph function, dopamine agonists represent the first-line therapy. However, a subset of patients exhibits resistance to these drugs, and therefore, alternative treatments are desired. As activins inhibit prolactin gene expression through the inhibition of Pit-1 involving the p38MAPK pathway, in the present work, we studied the local activin system as an alternative inhibitory system for lactotroph hyperplasia treatment. We used two different mouse models of prolactinoma: transgenic mice with overexpression of the human chorionic gonadotropin $\beta$-subunit (hCG $\beta$ ) and mice lacking dopamine receptor type 2. In both models, females, but not males, develop lactotroph hyperplasia from the fourth month of life. We found reduced expression of pituitary activin subunits and activin receptors in hyperplastic pituitaries from both models compared with wildtype counterparts. Consequently, hyperplastic pituitaries presented a reduced activininhibitory action on prolactin secretion. Additionally, while female wild-type lactotrophs presented high levels of phospho-p38MAPK, it was lost in prolactinomas, concomitant with decreased activin expression, increased Pit-1 expression and tumour development. In contrast, male pituitaries express higher mRNA levels of activin subunits $\beta A$ and $\beta B$, which would suggest a stronger activin inhibitory function on lactotrophs, protecting this sex from tumour development, despite genotype. The present results highlight the importance of the activin inhibitory action on lactotroph function and place the local activin system as a new target for the treatment of dopamine agonist-resistant prolactinomas.
\end{abstract}

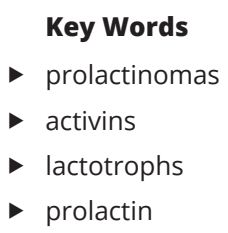

Journal of Endocrinology (2020) 244, 415-429

\section{Introduction}

Pituitary tumours account from 10 to $15 \%$ of all intracranial neoplasms with a relatively high prevalence, accounting for 1 case per 1000 (Mete et al. 2018). These tumours are usually benign and can present slow growth rates over many years. However, besides their benign features, pituitary tumours may cause significant clinical problems due to the 'mass effects' (headache and visual failure from optic chiasm compression) and hormone hypersecretion from functioning tumours (Kovacs et al. 2001, Farrell 2006). https://joe.bioscientifica.com https://doi.org/10.1530/JOE-19-0326
(C) 2020 Society for Endocrinology Published by Bioscientifica Ltd. Printed in Great Britain 
Prolactinomas, which derive from hypertrophy and hyperplasia of lactotroph cells, are the pituitary tumours with the highest incidence in the clinic (Ciccarelli et al. 2005). Sexual differences in the clinical manifestations, prevalence, tumour size, and behaviour have been widely described (Mindermann \& Wilson 1994, Gillam et al. 2006). In women, the hyperprolactinemia promotes alterations in the menstrual cycle that lead to an early clinical evaluation and, therefore, microprolactinomas are more frequent in this gender at the time of diagnosis (Fainstein Day et al. 2010). In contrast, in men, clinical manifestations due to hyperprolactinemia, such as sexual dysfunction or decreased libido, are underestimated and leads to a delay in diagnosis. Thus, in general, men attend a medical consultation with symptoms related to mass effects, due to the presence of macroprolactinomas (Colao et al. 2003, Wong et al. 2015a).

The primary goals in the treatment of prolactinomas are to normalize prolactin levels in order to restore fertility and sexual function, to reduce the tumour mass to potentially relieve the visual defects and headaches and to preserve the residual pituitary function (Liu \& Couldwell 2004, Gillam et al. 2006, Schlechte 2007).

As the primary inhibitory control of prolactin synthesis and release is mediated by dopamine, the standard treatment for patients with prolactinoma is with dopamine agonists. Even though most prolactinomas are successfully treated with these agonists (Kars et al. 2010, Colao \& Savastano 2011, Wong et al. 2015b), a reasonable percentage of patients do not respond to this therapy, even at high doses of dopamine agonists (Vroonen et al. 2012). To date, there is no alternative treatment for dopamine agonist-resistant prolactinomas (DARPs). Radiotherapy becomes the next therapeutic option, but with limited efficiency (Molitch 2014), and then, trans-sphenoidal surgery is indicated (Primeau et al. 2012, Smith et al. 2015). However, even after surgery, aggressive prolactinomas often recur. Thus, the management of DARPs remains a challenge, and new therapeutic approaches for the inhibition of exacerbated lactotroph function are necessary (Maiter 2019).

Among the growth factors participating in the intrapituitary regulation, activins have been proposed as potent inhibitors of lactotroph proliferation and prolactin secretion (Lacerte et al. 2004, de Guise et al. 2006, Lebrun 2009).

Activins and inhibins are dimeric protein hormones, members of the TGF $\beta$ family, first described for their stimulatory (activin) and inhibitory (inhibin) effects on follicle-stimulating hormone (FSH) production and secretion by gonadotroph cells (Keogh et al. 1976, Vale et al. 1986). Activins are homodimers of beta ( $\beta$ ) subunits. In the pituitary, the isoforms most commonly synthesized are Activin A ( $\beta \mathrm{A}-\beta \mathrm{A})$ and Activin B ( $\beta \mathrm{B}-\beta \mathrm{B})$, which act as autocrine/paracrine molecules. Pituitary activin function is antagonized by inhibins, betaglycan and follistatins (Thompson et al. 2005). Inhibins are heterodimers of an $\alpha$-specific subunit with a $\beta$ A-subunit (Inhibin A) or a $\beta \mathrm{B}$-subunit (Inhibin B). Although they are locally synthesized, the gonads represent the primary source of inhibins, and therefore, they mostly regulate pituitary activin function as endocrine factors (Makanji et al. 2014).

Betaglycan acts as a local functional inhibitor of activin binding and signalling (Lewis et al. 2000, Wiater et al. 2009). Acting as a co-receptor, it promotes a specific interaction between inhibins and the activin type II receptor preventing the recruitment of the activin type I receptor and the initiation of the intracellular activin signalling (Lewis et al. 2000, Bilezikjian et al. 2012).

Another critical player in the local control of activin action is follistatin (FST). FST has been characterized as a specific activin-binding protein that can bind activins in the extracellular compartment, with high affinity, neutralizing its effects (Gregory \& Kaiser 2004). FST present two primary isoforms: FST288 and FST315, which originated from alternatively splicing (Shimasaki et al. 1988, Sugino et al. 1997, Lerch et al. 2007). While both isoforms bind activins with high affinity, FST288 also has a high affinity for heparan-sulfate proteoglycans of the cell surface, and mostly prevent the potential autocrine and paracrine action of activins. In contrast, FST315 has no affinity for heparan-sulfate proteoglycans and is, predominantly, a circulating isoform (Welt et al. 2002, Schneyer et al. 2004).

It has been described that disturbances in activins functionality can lead to the development of endocrine and neuroendocrine tumours (Risbridger et al. 2001, Namwanje \& Brown 2016). On the other hand, an aberrant FST expression has been observed in a variety of solid tumours, including gonadal, gastric and hepatocellular carcinoma (Shi et al. 2016). However, to date, the participation of activins and inhibins in prolactinoma development is still not fully elucidated (Davis et al. 2001, Farrell 2006).

Since activins are involved in the inhibition of lactotroph function, in the present work, we investigated alterations in the activin-inhibin system in lactotroph hyperplasia development in two different animal experimental models of prolactinoma. (c) 2020 Society for Endocrinology Published by Bioscientifica Ltd. Printed in Great Britain 


\section{Materials and methods}

\section{Animals}

hCG $\beta+$ transgenic mice, with FVB/N background, overexpress the human chorionic gonadotropin $\beta$-subunit (hCG $\beta$ ) under the control of human ubiquitin C promoter. Generation and genotyping have been previously described (Rulli et al. 2002). These mice were used at six months at which time the pituitaries from hCG $\beta+$ females were hyperplastic (Rulli et al. 2002, Faraoni et al. 2017).

Drd2ko (KO) mice, (official strain designation B6.129S2-Drd2tm1Low/J by the Induced Mutant Resource at The Jackson Laboratory), were generated by targeted mutagenesis of the Drd2 gene in embryonic stem cells, as previously described (Kelly et al. 1997, Asa et al. 1999). Both isoforms of Drd2 (D2L and D2S) are non-functional in mutant mice. Drd2+/+ (WT), heterozygous, and Drd2-/(Drd2ko, KO) mice were identified by PCR of genomic DNA as described previously (Díaz-Torga et al. 2002). These mice were used at 8 months at which time the pituitaries from Drd2-/- $(\mathrm{KO})$ females were hyperplastic (Díaz-Torga et al. 2002).

All studies were performed in hCG $\beta$ and Drd 2 mice of both genders and genotypes. Animals were housed in groups of four or five with mixed genotypes in a temperature-controlled room with lights on at 07:00 $\mathrm{h}$ and off at 19:00 $\mathrm{h}$ and were given free access to laboratory chow and tap water. All experimental procedures were performed according to the NIH Guidelines for Care and Use of Experimental Animals (Division of Animal Welfare, Office for Protection of Research Risks, National Institutes of Health, A\#5072-01) and were approved by the Institutional Animal Care and Use Committee of the Instituto de Biología y Medicina Experimental (IBYME).

Mice were killed by decapitation and trunk blood was collected. All pituitaries were weighted after removal. Serum samples were separated by centrifugation and stored at $-20^{\circ} \mathrm{C}$ for biochemical analyses. Anterior pituitaries of different experimental groups were stored at $-70^{\circ} \mathrm{C}$ for posterior analyses.

\section{RNA isolation and gene expression assays}

Anterior pituitaries were collected and processed in TRIzol Reagent (Invitrogen), and total RNA was isolated according to the manufacturer's protocol. One microgram of RNA was reverse-transcribed in a $20 \mu \mathrm{L}$ reaction volume using MMLV-RT (Promega) and random primers (Biodynamics). For quantitative real-time RT-PCR (QRT-PCR) primers sets were designed for the specific amplification, and primer sequences used are shown in Table 1.

To normalize the differences in the amount of starting template between samples, we previously assayed the appropriate internal control (housekeeping gene). Two reference genes were evaluated: the $60 \mathrm{~S}$ ribosomal protein L38 (Rpl38) and Cyclophilin B (Cypb). The qPCR efficiency of each pair of primers was tested using serially diluted samples and was established through calibration curves. $C y p b$ was selected as the most proper housekeeping gene due to the parallelism presented between its slope of the regression line (and consequently on the value of the correlation coefficient) with the slope of other genes evaluated. Moreover, as we show in Table 2, the expression levels of $C y p b$ did not change regardless of the experimental group, ensuring a proper normalization within the samples and a robust QRT-PCR analysis.

Each sample was assayed in duplicate using the Fast Start Universal SYBR Green Master Rox (Roche) on a CFX96 Touch Real-Time PCR Detection System (BioRad). Differences in the cDNA target gene expression were quantified by comparing the threshold cycle (CT) with that of $C y p b$ using the comparative CT method $(\Delta \Delta \mathrm{CT})$.

FST288 isoform was amplified using a specific QuantiTect Primer Assay (QIAGEN, catalogue number QT00105483). Since FST288 exhibited CT values near the detection limit of the QRT-PCR assay, a semi-quantitative

Table 1 qPCR primer sequences.

\begin{tabular}{|c|c|}
\hline Gene & Accession no. \\
\hline Inhba & NM_008380.2 \\
\hline Inhbb & NM_008381.4 \\
\hline Inha & NM_010564.5 \\
\hline Betaglycan & NM_011578.4 \\
\hline Acvr1b & NM_007395.4 \\
\hline Acvr $2 b$ & NM_001313757.1 \\
\hline Pit-1 & NM_008849.5 \\
\hline CyclophilinB & NM_011149.2 \\
\hline Gapdh & NM_008084.3 \\
\hline
\end{tabular}

\begin{tabular}{l} 
Forward primer sequence $\left(5^{\prime}-3^{\prime}\right)$ \\
\hline GATCATCACCTTTGCCGAGT \\
TCAGCTTTGCAGAGACAGATGG \\
GGGGATCCTGGAATAAGGCG \\
AGCTGCCAAAGTGTGTGACTC \\
CAAATCAGAGGGTGGGGACC \\
TTTGGCTGCGTTTGGAAAGCTC \\
GTGATGTCCACAGCGACAGG \\
GACCCTCCGTGGCCAACGA \\
GTGCCAGCCTCGTCCCGTAG
\end{tabular}

\begin{tabular}{l}
\hline Reverse primer sequence $\left(5^{\prime}-3^{\prime}\right)$ \\
\hline TGGTCCTGGTTCTGTTAGCC \\
ACACCTTGACCCGTACCTTC \\
GTGGCACCTGTAGCTGGGAA \\
CGGACTGGACTCCTTCATGTT \\
TGGACTCCTCCAGAATTGCAT \\
ACGACTGCTTGTCCTGAAGTGG \\
ACTCAGGGTGTGGTCTGGAA \\
ACGACTCGTCCTACAGATTCATCTC \\
GTGCCGTTGAATTTGCCGTGAGTG
\end{tabular}


Table 2 Average of $\mathrm{Ct}$ values showing stable expression of Cypb within samples of different groups.

\begin{tabular}{|c|c|c|c|}
\hline Ct values $(\bar{x})$ & Cypb & $\operatorname{lnhBB}$ & $\Delta C t$ values \\
\hline F wt & 26.89 & 30.12 & 3.23 \\
\hline $\mathrm{F} \beta+$ & 27.01 & 31.60 & 4.59 \\
\hline M wt & 26.95 & 29.93 & 2.98 \\
\hline $\mathrm{M} \beta+$ & 26.76 & 29.42 & 2.66 \\
\hline
\end{tabular}

(sqPCR) following a protocol of 40 cycles was used. Agarose gels were digitalized, and the density of bands was measured with the software Image $(\mathrm{NIH}$, National Institutes of Health). The sqPCR results are expressed relative to Gapdh.

\section{Radioimmunoassay (RIA)}

Serum PRL, FSH and LH levels were measured by RIA using mouse-specific reagents provided by the National Institute of Diabetes and Digestive and Kidney Diseases and National Hormone and Pituitary Program (Dr. A. F. Parlow, NHPP, Torrance, CA). Assays were performed using $10 \mu \mathrm{L}$ (PRL), $70 \mu \mathrm{L}$ (FSH and $\mathrm{LH}$ ) serum samples in duplicate. Results are expressed in nanograms per millilitre. The inter- and intra-assay coefficients of variation were 6.9 and $11.6 \%$ (PRL), 8.0 and $12.2 \%$ (FSH) and 7.5 and $11.2 \%(\mathrm{LH})$, respectively.

\section{Western blot}

Anterior pituitaries were homogenized and processed as previously described (Recouvreux et al. 2011). Membranes were incubated overnight at $4^{\circ} \mathrm{C}$ with mouse anti-FST antibody (1:150, sc 365003; Santa Cruz Biotechnology, Inc.), and then 1-h incubation with mouse anti-IgGK secondary antibody (1:200, sc 516102; Santa Cruz Biotechnology, Inc.) was performed. After washing in PBS 0.05\% Tween 20 (PBS-T), the immunoreactive bands were detected by the chemiluminescence released by the oxidation of the luminol substrate $(250 \mathrm{mM})$, in the presence of $\mathrm{H}_{2} \mathrm{O}_{2}$. The chemiluminescence was detected in a G:box chemi-HR16 (Syngene, Frederick, MD, USA) and bands intensity was quantified using ImageJ software (National Institutes of Health, Bethesda, MD, USA). GAPDH was used as loading control: anti-GAPDH primary antibody (1:150, sc 365062; Santa Cruz Biotechnology, Inc., Santa Cruz, CA, USA). Between protocols, membranes were stripped of bound antibodies with stripping buffer (100 mM 2-Mercaptoethanol, 2\% SDS, 62.5 mM Tris- $\mathrm{HCl}$ $\mathrm{pH}$ 6.8) and incubated at $50^{\circ} \mathrm{C}$ for 30 min with agitation, and then washed three times for $10 \mathrm{~min}$ in PBS-T at room temperature.

(C) 2020 Society for Endocrinology Published by Bioscientifica Ltd. Printed in Great Britain

\section{Confocal laser scanning microscopy}

Pituitary glands of WT and hCG $\beta+$ female mice were placed in Crioplast (Biopack, Buenos Aires, Argentina) and immersed in liquid nitrogen for a few minutes until the solidification of the embedding medium. Pituitaries were sectioned using a cryostat and slices were fixed in absolute methanol as previously described by Perez et al. (2018). Tissue sections were blocked for $1 \mathrm{~h}$ in $5 \%$ PBS-BSA, and incubated overnight with primary antibodies (anti-ActRIB, Abcam, USA, dilution 1:100; or anti phospho-p38, Cell Signalling, 1:200). After that, tissues were incubated with anti-PRL or anti-FSH, Dr A. Parlow, National Hormone and Pituitary Program, Torrance, CA, USA; dilution 1:1000) for $1 \mathrm{~h}$, and further incubated with Alexa 488 and Alexa 594 secondary antibody (1:1000; Invitrogen) for $1 \mathrm{~h}$. Finally, sections were mounted with fluoromount (Sigma) containing 4',6-diamidino-2-phenylindole (DAPI). Negative controls were performed replacing the primary antibody with $1 \%$ PBS-BSA to validate the specificity of the immunostaining. Images were obtained using the inverted confocal laser scanning microscope FluoView FV 1000 (Olympus). The analysis of confocal microscopy images was performed using the software FV10-ASW 1.6 Viewer.

Three slides (corresponding to three pituitaries) were analyzed for each group. For the morphometric analysis, a total of 5000 pituitary cells were examined in randomly chosen fields of each glass slide and quantified in order to establish the percentage of lactotroph (PRL+) immunoreactive for ActRIB $(n=3, P=0.05)$.

\section{Ex vivo assay}

Female hCG $\beta+$ and WT littermates (6-month-old) were killed and anterior pituitaries were collected in $300 \mu \mathrm{L}$ of Dulbecco Eagle's Modified Medium (DMEM) supplemented with $2.5 \mathrm{v} / \mathrm{v}$ foetal bovine serum (Natocor, Argentina), $15 \mathrm{v} / \mathrm{v}$ horse serum (Internegocios, Argentina), and $20 \mu \mathrm{g} / \mathrm{mL}$ gentamicin (Sigma-Aldrich). Anterior pituitaries were cut into small fragments and washed to remove traces of blood. After $2 \mathrm{~h}$ of incubation with supplemented media at $37^{\circ} \mathrm{C}$ in a $\mathrm{CO}_{2}$ incubator, to stabilize the tissue, tissues were washed with fresh medium and stimulated for $45 \mathrm{~min}$ at $37^{\circ} \mathrm{C}$ with $20 \mathrm{ng} / \mathrm{mL}$ of Recombinant Human Activin A (NIH, Lot \# NU1-4345) in $250 \mu \mathrm{L}$ of serum-free DMEM or with $250 \mu \mathrm{L}$ of serum-free DMEM alone (control). Medium samples $(20 \mu \mathrm{L})$ were taken at 15 , 30 , and $45 \mathrm{~min}$, and stored at $-20^{\circ} \mathrm{C}$ until measurement of PRL by RIA. 


\section{Statistical analysis}

Results are expressed as mean \pm S.E.M. Data were analyzed by Student's $t$-test when two groups were compared. Two-way ANOVA was performed for female vs male analyses, as the effects of two factors (genotype and sex) were evaluated, followed by Tukey's post hoc test when interaction was significant. The morphometric study of ActRIB protein expression in the lactotroph population was performed using the chi-square test. The degree of activin-inhibitory action in the ex vivo assay was evaluated by two-way ANOVA followed by a Šídák post hoc analysis. $P<0.05$ was considered significant. Data were transformed when required.

\section{Results}

\section{Sexual differences in the development of lactotroph hyperplasia in hCG $\beta$ and Drd 2 mice}

As previously described by Rulli et al. (2002) and Kelly et al. (1997), only hCG $\beta+$ and Drd2ko (KO) female mice develop lactotroph hyperplasia at 6 and 8 months of age, respectively, evidenced by an enlargement of pituitary size
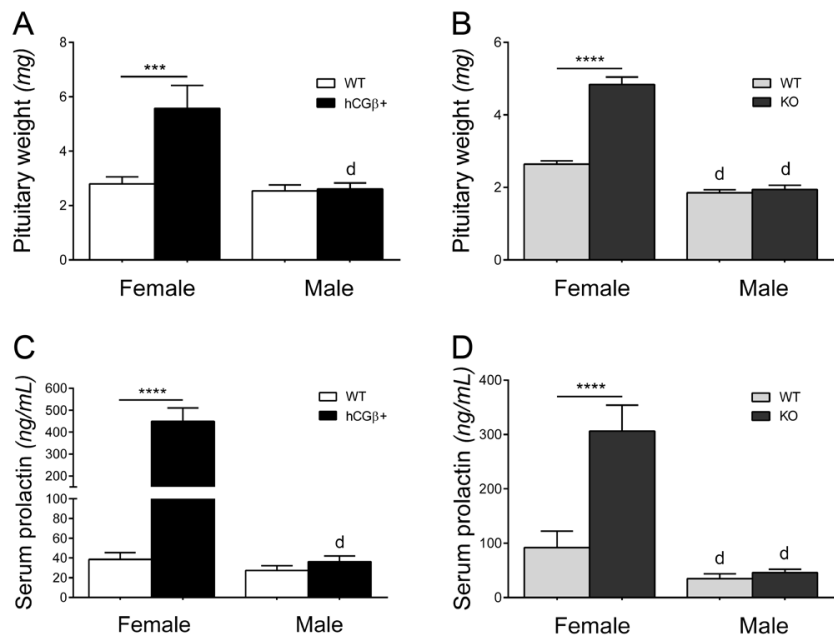

Figure 1

Pituitary weight ( $A$ and $B$ ) and serum PRL levels ( $C$ and $D$ ) of 6-month-old hCG $\beta$ and 8-month-old Drd2 mice. Data analyzed by two-way ANOVA (sex $\times$ genotype), followed by a Tukey's post hoc analysis when the interaction effect was significant. Data are expressed as mean \pm S.E.M. $n=8-10$ /group. (A) hCG $\beta$ mice. Interaction $P=0.0338$. *** $P<0.001 \mathrm{hCG} \beta+$ vs WT female. $d P<0.0001$ hCG $\beta+$ male vs hCG $\beta+$ female. (B) Drd2 mice. Interaction $P<0.0001$. $* * \star \star P<0.0001 \mathrm{KO}$ vs WT female. $\mathrm{d} P<0.0001$ male vs female. (C) hCG $\beta$ mice. Interaction $P<0.0001$. **** $P<0.0001$ hCG $\beta+$ vs WT female. $d p<0.0001$ hCG $\beta+$ male vs hCG $\beta+$ female. (D) Drd2 mice. Interaction $P=0.0257$. $* \star \star \star ~ P<0.0001 \mathrm{KO}$ vs WT female. $\mathrm{d} P<0.0001$ male vs female.
(Fig. 1A and B) and hyperprolactinemia (Fig. 1C and D) when compared to their WT littermates.

\section{Pituitary $\beta A$-subunit and $\beta B$-subunit mRNA expression is reduced in hCG $\beta+$ and Drd2ko (KO) females}

To better understand the role of activins in prolactinoma development, we first analyzed, by quantitative realtime PCR (qRT-PCR), the pituitary mRNA expression of $\beta$ (beta) subunits in both animal models of lactotroph hyperplasia. We found a markedly reduced pituitary mRNA expression of both $\beta \mathrm{A}$ (Inhba) and $\beta \mathrm{B}$ (Inhbb) subunits in hCG $\beta+$ (Fig. 2A and $\mathrm{C}$, respectively) and $\mathrm{KO}$ (Fig. 2B and D, respectively) females when compared to their wild type (WT) littermates. Moreover, a significant gender difference was observed in both experimental models. Male pituitaries presented significantly higher expression of both, Inhba and Inhbb, compared to females, regardless of the genotype, and concomitant with the absence of lactotroph hyperplasia development in this gender (Fig. 2).
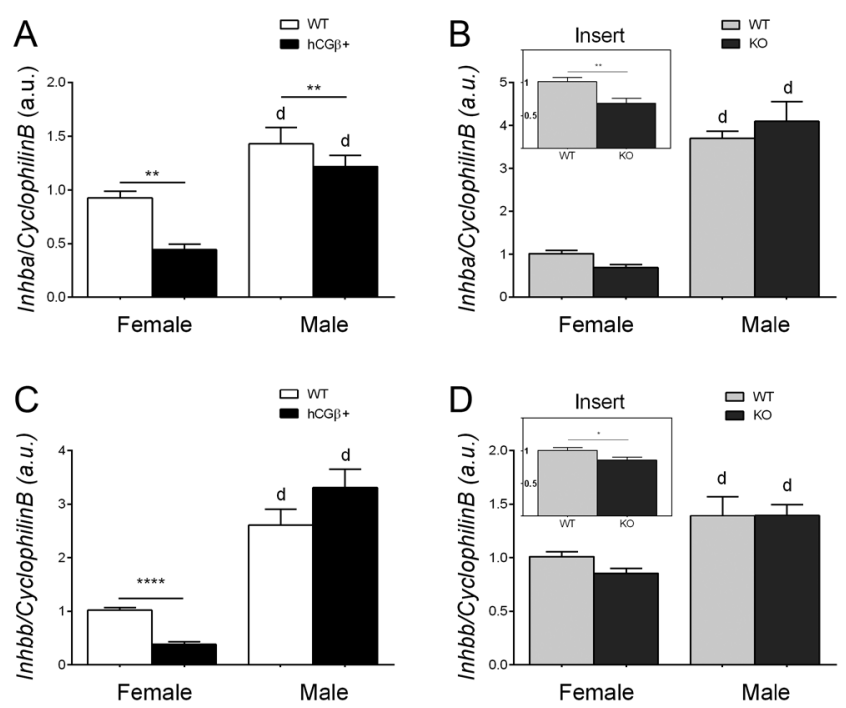

Figure 2

Pituitary Inhba and Inhbb expression in hCG $\beta$ and Drd 2 mice pituitaries. mRNA transcripts were amplified with specific primers by qRT-PCR and normalized to CyclophilinB. Results are expressed relative to those for WT females. Data analyzed by two-way ANOVA (sex $\times$ genotype), followed by a Tukey's post hoc analysis when interaction was significant. Data are expressed as mean \pm S.E.M. $n=8-10$ /group. (A) hCG $\beta$ mice. Inhba mRNA expression. Interaction ns. ${ }^{*} P<0.01$ (genotype). $\mathrm{d} P<0.0001$ (sex). (B) Drd2 mice. Inhba mRNA expression. Interaction ns. d $P<0.0001$ (sex). Insert: ${ }^{*} \mathrm{p} P<0.01 \mathrm{KO}$ vs WT female. Data analyzed by Student's $t$ test. (C) hCG $\beta$ mice. Inhbb mRNA expression. Interaction $P<0.0001$.

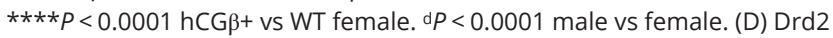
mice. Inhbb mRNA expression. Interaction ns. d $P<0.0001$ (sex). Insert: $\star P<0.05$ KO vs WT. Data analyzed by Student's $t$ test. 
A
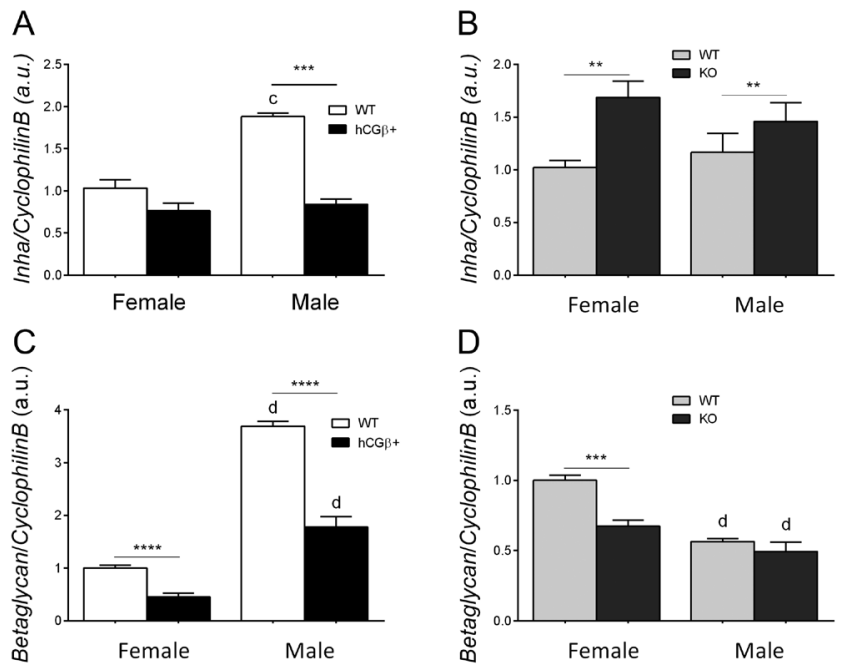

Figure 3

Pituitary mRNA expression of $\alpha$-subunit (Inha) and betagycan in hCG $\beta$ and Drd2 mice. mRNA transcripts were amplified with specific primers by qRT-PCR and normalized to CyclophilinB. Results are expressed relative to those for WT females. Data analyzed by two-way ANOVA (sex $\times$ genotype), followed by a Tukey's post hoc analysis when the interaction effect was significant. Data are expressed as mean \pm S.E.M. $n=6$-8/group. (A) Inha mRNA expression in 6-month-old hCG $\beta$ mice pituitaries. Interaction $P<0.001 . c P<0.001$ WT male vs WT female. ${ }^{* \star *} P<0.001$ hCG $\beta+$ male vs WT male. (B) Inha mRNA expression in 8-month-old Drd2 mice pituitaries. Interaction ns. $* * P<0.01$ (genotype). (C) Betaglycan mRNA expression in pituitaries from hCG $\beta$ mice. Interaction ns. $* \star \star \star * P<0.0001$ (genotype). $\mathrm{d} P<0.0001$ (sex). (D) Betaglycan mRNA expression in pituitaries from Drd2 mice. Interaction $P<0.05$. $* \star \star P<0.001$ KO vs WT female. $d P<0.0001$ (male vs female).

\section{Pituitary inhibin $\alpha$-subunit and betaglycan expression in $\mathrm{hCG} \beta$ and Drd2 mice}

To determine levels of locally synthesized inhibins, antagonists of activin inhibitory functions on lactotrophs, we evaluated, by qRT-PCR, the mRNA expression of the specific inhibin $\alpha$-subunit (Inha) in pituitaries from both mouse models. Inha expression was found to be model specific. In hCG $\beta$ mice, higher levels of Inha were found in WT males compared to WT females (Fig. 3A). On the other hand, decreased pituitary Inha mRNA expression was observed in hCG $\beta+$ male mice when compared to their WT littermates. However, no genotype differences were found in females. In contrast, when we analyzed the pituitary Inha mRNA expression in Drd2 mice, we found increased expression levels in Drd2ko (KO) mice in both sexes, when compared to the respective WT littermates (Fig. 3B), without gender differences.

We next determined the pituitary mRNA expression of betaglycan, the co-receptor responsible for increasing the affinity of inhibins for ActRII. As observed in Fig. 3, decreased betaglycan mRNA expression levels was observed in the hyperplastic pituitaries from both, hCG $\beta+$ and Drd2ko (KO) females, when compared to their WT littermates (Fig. 3C and D, respectively). Moreover, decreased levels of pituitary betaglycan were also found in hCG $\beta+$ males when compared to their WT littermates (Fig. 3C). Additionally, and as observed for Inha expression, mouse model-specific gender differences were also found, with higher betaglycan expression in hCG $\beta$ males, but, in contrast, lower betaglycan expression in Drd2 males when compared to WT females (Fig. 3C and D, respectively). These results suggest that activin antagonism is differentially exerted in hCG $\beta$ and Drd2 mice.

Even though pituitary inhibins (A and B) can act as an autocrine and/or paracrine factor on lactotroph cells, it is known that inhibins are primarily synthesized by the gonads and mostly antagonize pituitary activin functions in an endocrine manner. In this context, we next evaluated the gonadal mRNA expression of the three subunits (Inhba, Inhbb, and Inha) in both hCG $\beta$ and Drd2 female mice by qRT-PCR. As observed in Fig. 4, ovaries from hCG $\beta+$ females showed a decreased mRNA expression of the three subunits when compared to their WT littermates (Fig. 4A, B and C).

In contrast, the gonadal mRNA expression of Inhba, $I n h b b$, and Inha was found increased in Drd2KO female mice ovaries (Fig. 4D, E and F) when compared to their WT littermates, suggesting that higher levels of gonadal inhibins may reach the pituitary by circulation in this model. This result, in addition to the elevated pituitary Inha expression found in $\mathrm{KO}$ female mice pituitaries (Fig. 3B), suggests an increased antagonism of pituitary activins by local and gonadal inhibins in KO female mice, concomitant with the development of lactotroph hyperplasia.

\section{Pituitary FST288}

Since FST288 is a functional and physiological antagonist of activin inhibitory function, we analyzed its local expression by semi-quantitative PCR (sq-PCR) and Western blot in pituitaries from female and male mice of both experimental models of prolactinoma. We found increased levels of FST288 (mRNA and protein) in hCG $\beta+$ female mice pituitaries when compared to their WT littermates (Fig. 5A and B), suggesting an antagonism of activin inhibitory function by FST288 in this group concomitant with the development of lactotroph hyperplasia.

On the other hand, neither gender nor genotype alterations in pituitary FST288 mRNA expression were observed in the Drd2 mouse model (Fig. 5C). 
A
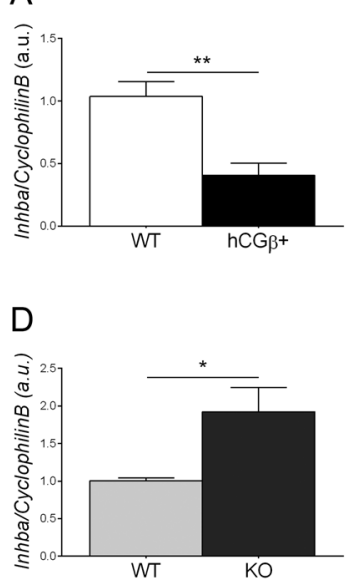

B
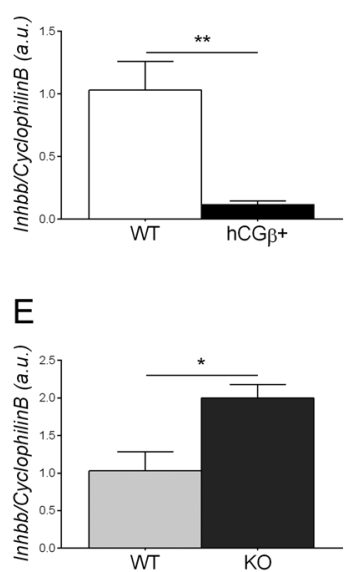

C

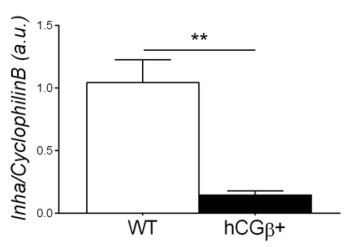

$\mathrm{F}$

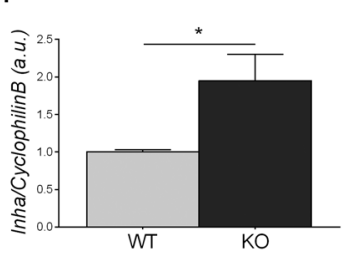

Figure 4

mRNA expression of Inhba, Inhbb and Inha in hCG $\beta+$ and Drd2ko (KO) female mice ovaries. mRNA transcripts were amplified with specific primers by $q R T-P C R$ and normalized to CyclophilinB. Results are expressed relative to those for WT females. Data were analyzed by Student's $t$ test and expressed as mean \pm S.E.M. ( $n=6 /$ group). (A, B and C) mRNA expression in 6-month-old hCG $\beta$ female mice ovaries; (A) Inhba (**P=0.01); (B) Inhbb (**P=0.01); (C) Inha $(* \star P=0.01)$. (D and E) mRNA expression in 8-month-old Drd2 female mice ovaries; (D) Inhba $\left({ }^{*} P=0.05\right) ;(\mathrm{E}) \operatorname{Inhbb}\left({ }^{*} P=0.05\right) ;(\mathrm{F}) \operatorname{lnha}\left({ }^{*} P=0.05\right)$.
Serum gonadotrophins levels in hCG $\beta$ and Drd2 mice

Due to the differences found among the two animal models of prolactinoma in the pituitary and ovary expression (Figs 3 and 4) and knowing that inhibin synthesis is closely related to gonadotrophins production (especially FSH), we measured serum FSH and LH levels in both mice. As expected, higher levels of serum FSH were

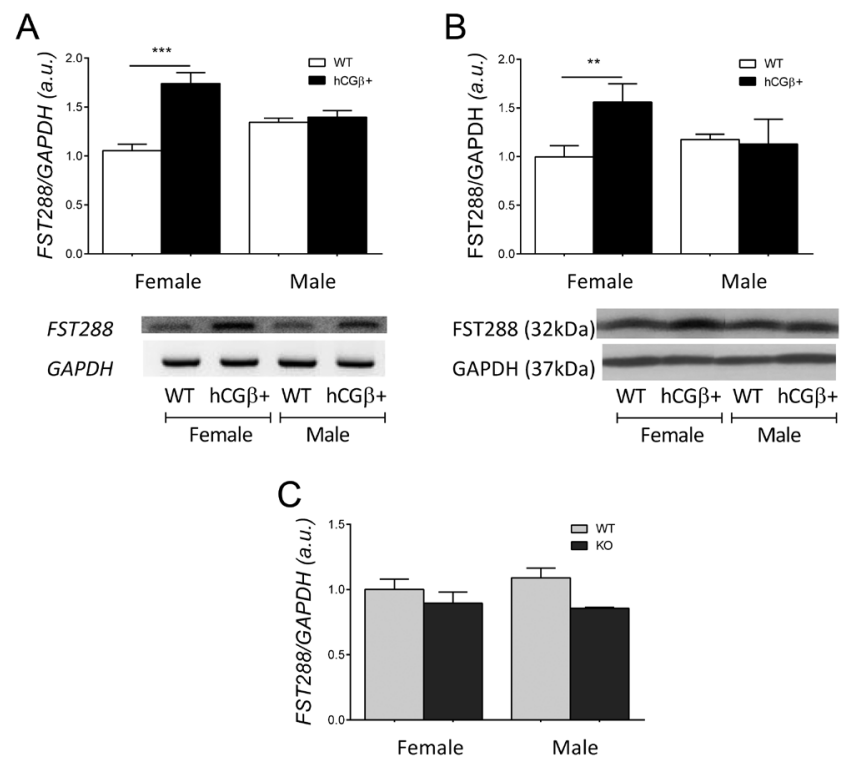

Figure 5

Pituitary FST288 expression in hCG $\beta$ (A and B) and Drd2 (C) mice. Data analyzed by two-way ANOVA (sex $\times$ genotype), followed by a Tukey's post hoc analysis when the interaction effect was significant. Data are expressed as mean \pm S.E.M. $n=6$-8/group. (A and C) FST (62 pb) mRNA transcripts were amplified by sqPCR, normalized to Gapdh (171 pb) and quantified by densitometry. Results are expressed relative to those for WT females ( $n=6 /$ group). (A) hCG $\beta$ mice. Interaction $P<0.01$. $* * * P<0.001$ hCG $\beta+$ vs WT female. Representative immunoreactive bands are shown. (C) Drd2 mice. Interaction ns. No differences were found between groups. (B) Protein FST288 expression in hCG $\beta$ mice pituitaries. Interaction $P<0.05$. $* * P<0.01$ hCG $\beta+$ vs WT female. Representative immunoreactive bands are shown. found in males, compared with females, in both animal models (Fig. 6A and B, respectively). Mice overexpressing hCG $\beta$ subunit presented lower FSH levels when compared to WT littermates (Fig. 6A), as previously described (Rulli et al. 2002). In contrast, Drd2ko (KO) females presented increased FSH levels (Fig. 6B) compared to WT, with no genotype differences in males.

Serum LH levels were found decreased in male and female Drd2KO mice without gender differences (Fig. 6D). In the hCG $\beta$ mouse model, males presented higher serum
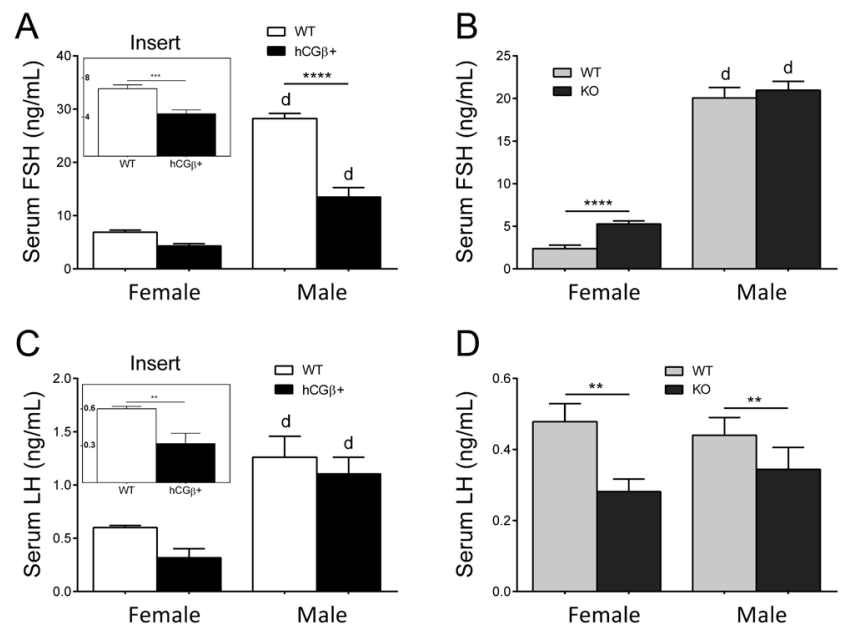

Figure 6

Serum gonadotrophin levels in hCG $\beta$ and Drd 2 mice. (A and B) Serum FSH levels measured by RIA (ng/mL). (A) hCG $\beta$ mice. Interaction $P<0.0001$. $\mathrm{d} P<0.001$ male vs female. $* \star \star \star P<0.0001 \mathrm{hCG} \beta+$ male vs WT male. Insert: $\star \star \star P<0.001 \mathrm{hCG} \beta+$ female vs WT female (with data analyzed by Student's $t$ test). (B) Drd2 mice. Interaction $P=0.0002 .{ }^{* \star * * P} P<0.0001 \mathrm{KO}$ female vs WT female. $d P<0.0001$ male vs female. (C and D) Serum LH levels measured by RIA (ng/mL). (C) hCG $\beta$ mice. Interaction ns. ${ }^{d} P<0.01$ (sex). Insert: $* * P<0.01 \mathrm{hCG} \beta+$ female vs WT female (with data analyzed by Student's $t$ test). (D) Drd2 mice Interaction ns. ${ }^{* *} P<0.01$ (genotype). (A, B, C and D) Data analyzed by two-way ANOVA (sex $\times$ genotype), followed by a Tukey's post hoc analysis when interaction was significant. Data are expressed as mean \pm S.E.M. $n=8$-10/group. 

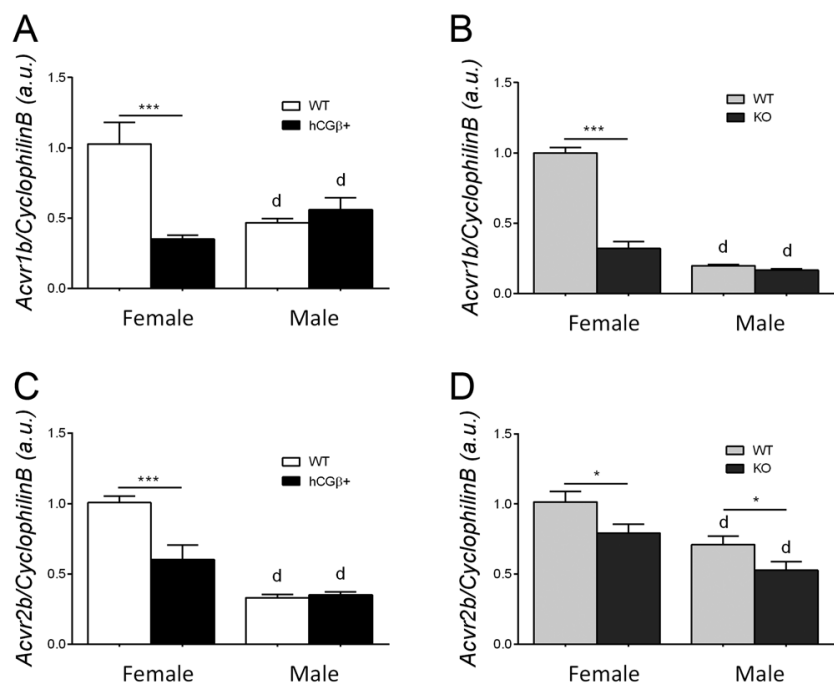

Figure 7

Pituitary mRNA expression of activin receptors in 6-month-old hCG $\beta$ and 8-month-old Drd2 mice. mRNA transcripts were amplified with specific primers by qRT-PCR and normalized to CyclophilinB. Results are expressed relative to those for WT females. Data were analyzed by two-way ANOVA (sex $\times$ genotype), followed by a Tukey's post hoc analysis when the interaction effect was significant. Data are expressed as mean \pm S.E.M. $n=6-8 /$ group. (A and B) Activin type IB receptor mRNA expression (Acvr1b). (A) hCG $\beta$ mice. Interaction $P<0.001 . * \star \star P<0.001 \mathrm{hCG} \beta+$ vs WT female. $\mathrm{d} P<0.05$ male vs female. (B) Drd2 mice. Interaction $P<0.001$. $\star * \star P<0.001$ KO vs WT female. $d P<0.0001$ male vs female. (C and $D$ ) Activin type IIB receptor mRNA expression (Acvr2b). (C) hCG $\beta$ mice. Interaction $P<0.05$. $* \star \star * P<0.001$ hCG $\beta+$ vs WT female. d $P<0.001$ male vs female. (D) Drd2 mice. Interaction ns. $* P<0.05$ (genotype). $d P<0.001$ (male vs female).

LH than females, without genotype differences. However, hCG $\beta+$ females presented lower LH levels compared to their WT littermates (Fig. 6C).

These results suggest that, in females, pituitary and ovary inhibins expression follows FSH but not LH serum levels in each mouse model.

\section{Pituitary mRNA expression of activin receptors in hCG $\beta$ and Drd2 mice}

The activin inhibitory action on lactotroph function also depends on the expression of activin receptors. Then, we next analyzed the mRNA expression of activin receptors in pituitaries from hCG $\beta$ and Drd2 mice by qRT-PCR. As observed in Fig. 7, pituitary mRNA expression of activin type IB (Acvr1b) and type IIB (Acvr2b) receptors was found reduced in hyperplastic pituitaries from both mouse models (hCG $\beta+$ and KO females) when compared to their WT littermates. Moreover, we also found a significant gender difference, as the expression of Acvr $1 b$ and $A c v r 2 b$ was significantly lower in male pituitaries compared to females in both mouse models (Fig. 7A, B, C and D).

\section{Activin type IB receptor (ActRIB) expression in lactotroph and gonadotroph cells of WT and hCG $\beta+$ female mice}

The expression of ActRIB in gonadotroph population is well known. However, this receptor was also described in lactotroph cell lines and human prolactinomas (Lacerte et al. 2004, de Guise et al. 2006). Then, we next assayed the ActRIB protein expression, specifically in the lactotroph population from normal and hyperplastic $\beta$ hCG female pituitaries, through double immunostaining of PRL/ActRIB (Fig. 8A and B), using confocal laser scanning microscopy. Additionally, ActRIB expression in gonadotrophs was evaluated by double immunostaining of FSH/ActRIB (Fig. 8C and D).

As shown in Fig. 8, the ActRIB remains expressed normal as well as in hyperplastic lactotrophs (PRL+), and in gonadotroph population (FSH+) from WT as well as hCG $\beta+$ pituitaries.

The morphometric analysis (Table 3) shows that, as expected, the lactotroph population significantly increased in hCG $\beta+$ hyperplastic pituitaries (column A). The pituitary ActRIB expression was not significantly altered (column B). However, the proportion of lactotrophs ActRIB+/total lactotrophs (column C) was found decreased in hyperplastic pituitaries from hCG $\beta+$ females (Fig. 9).

\section{Inhibition of prolactin secretion by activin in an ex vivo assay}

To evaluate whether the activin inhibitory action on prolactin secretion could be impaired in hyperplastic pituitaries due to the decreased ActRIB expression observed in this group, female WT and hCG $\beta+$ pituitaries were incubated in serum-free medium containing human recombinant Activin A (Act A) or medium alone (control). Samples were taken at different times, and prolactin release was assayed by RIA. Prolactin release increased with time, in both groups (Table 4). As expected, hyperplastic tissues secreted higher levels of prolactin than WTs, and the increase in prolactin secretion was lower in tissues treated with activin A, as a result of its inhibitory action on lactotroph function. Then, activin A inhibited PRL secretion in tissues from both genotypes. To compare the degree of activin inhibitory action in each group, data was evaluated as fold change $45 \mathrm{~min} / 15 \mathrm{~min}$ (Fig. 10). The two-way ANOVA showed a significant interaction $(P=0.0039)$, indicating that the inhibitory effect was different in each group. In fact, de degree of inhibition 

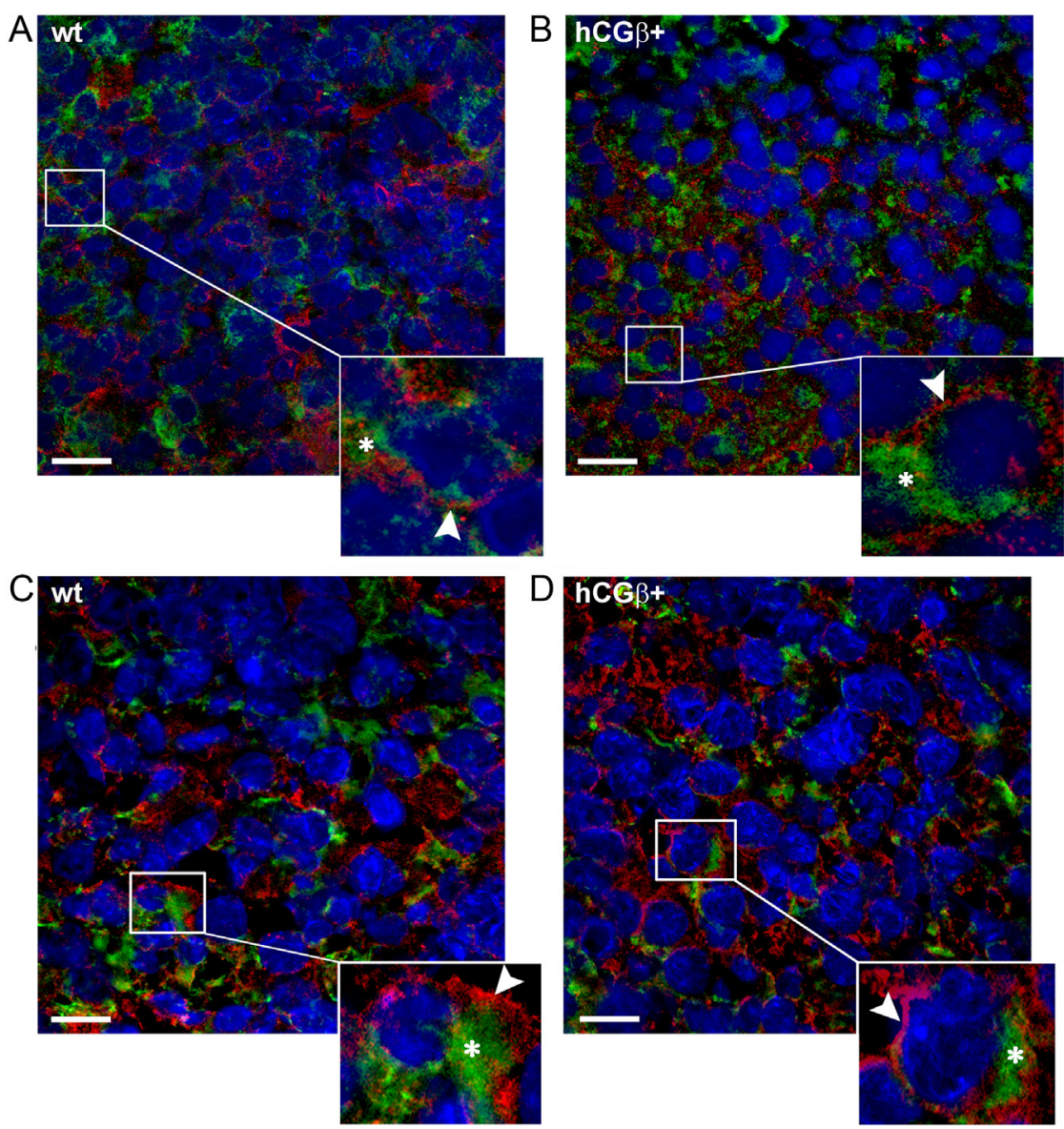

\section{Figure 8}

Activin type IB receptor expression in lactotrophs and gonadotrophs from $\mathrm{hCG} \beta$ female mice pituitaries. (A and B) Identification of ActRIB (red, arrowhead) and prolactin (green, *) by double indirect immunofluorescence in WT $(A)$ and $h C G \beta+$ (B) female mice pituitaries. (C and D) Identification of ActRIB (red, arrowhead) and FSH (green, *) by double indirect immunofluorescence in WT (C) and hCG $\beta+$ (D) female mice pituitaries. Nuclei were immunostained with DAPI (blue). Scale $\operatorname{bar}=20 \mu \mathrm{m}$

was about 53\% in WT tissues while it was about $41 \%$ in hyperplastic pituitaries.

\section{Signalling pathway involved}

Although the $\mathrm{pSmad} 2 / 3$ pathway represents the canonical signalling used by activins as well as TGF $\beta 1$, activation of other signalling cascades have also been described (Engel et al. 1999, Derynck \& Zhang 2003). In fact, activininhibition of lactotroph function involves the inhibition of Pit-1 through the p38MAPK pathway in a Smadindependent manner (de Guise et al. 2006). Pit-1 (or POU class 1 homeobox 1, POU1F1) is a critical pituitary-specific transcription factor involved in the development of the pituitary gland and, specifically, in the differentiation and proliferation of lactotrophs, somatotrophs and thyrotrophs (Szeto et al. 1996).
When pituitary Pit-1 expression was evaluated by real-time qPCR in the two mouse models, we observed, as expected, an increase of Pit-1 mRNA levels in hyperplastic pituitaries (hCG $\beta+$ and $\mathrm{KO}$ females), compared with their WT littermates (Fig. 11A and B), in accordance with increased proliferation in lactotroph population, while no genotype difference in Pit-1 expression was observed in males, despite genotype.

Then, we next assayed phospho-p38MAPK (p-p38) expression, specifically in lactotroph population (PRL+ cells), by double immunostaining using confocal laser scanning microscopy, in hCG $\beta$ female pituitaries. As observed in Fig. 12, upper panel, almost all PRL+ cells express p-p38 in female WT-pituitaries suggesting a marked activin inhibition in this group. However, few lactotrophs express p-p38 in hyperplastic pituitaries from

Table 3 Morphometric analysis: double immunostaining of ActRIB protein expression in lactotroph population (PRL+) from hCG $\beta$ female mice.

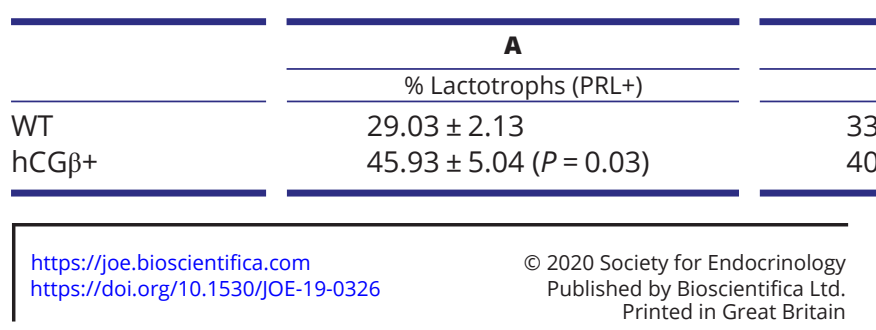




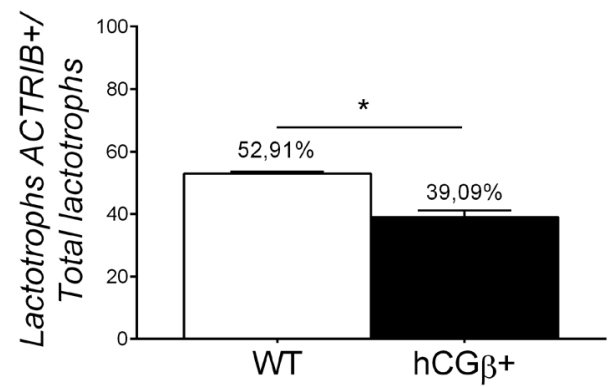

\section{Figure 9}

Percentage of lactotrophs expressing ActRIB/ total lactotrophs. A total of 5000 pituitary cells were examined in randomly chosen fields of each glass slide and quantified in order to establish the percentage of lactotroph (PRL+) immunoreactive for ActRIB in female WT and hCG $\beta+$ pituitaries. Data analyzed by chi-square test, $n=3, * P=0.05, P<0.001$.

hCG $\beta+$ female (lower panel), and this is concomitant with decreased activin expression and increased Pit-1 expression, suggesting that a lower activin-inhibitory action could be involved in lactotroph hyperplasia development in this group.

\section{Discussion}

Although activins are known to induce FSH production from gonadotroph population, they were described as negative regulators of lactotroph function: cell proliferation and PRL production (Lacerte et al. 2004, Bilezikjian et al. 2012). In this work, we studied the pituitary activin-inhibin system in two animal models of lactotroph hyperplasia: hCG $\beta$ and Drd2 mice. The expression of activin $\beta \mathrm{A}$ and $\beta \mathrm{B}$ subunits was found significantly decreased in pituitaries from hCG $\beta+$ and $\mathrm{KO}$ females, concomitant with the development of lactotroph hyperplasia. In contrast, higher mRNA expression of activin subunits was observed in male pituitaries, which would suggest increased bioavailability of activins, and thus, stronger activin inhibitory function on lactotroph population, protecting this sex from hyperplasia development in both mouse models (Kelly et al. 1997,
Rulli et al. 2002). Additionally, a reduced proportion of lactotrophs expressing ActBIR was observed in hCG $\beta+$ female pituitaries compared to WTs. In accordance, a weaker inhibitory action of activin on PRL secretion was found in hyperplastic pituitaries compared to that observed in WTs. All these results suggest that reduced activin inhibitory action could be involved in the development of lactotroph hyperplasia in females from both animal models.

Disruptions on activins inhibitory function have been previously proposed to be related to the development of endocrine and neuroendocrine tumours (Risbridger et al. 2001, Bilezikjian et al. 2004, Namwanje \& Brown 2016). The decreased expression of Inhba and $I n h b b$ found in pituitaries from hCG $\beta+$ and Drd2KO females suggests a reduced bioavailability of activins in these groups, and this fact could be related to lactotroph hyperplasia development.

On the other hand, an essential role in the regulation of local activin function is given by its antagonists. Inhibins and follistatins antagonize activin function in the pituitary by preventing activin binding to its receptors (Suszko \& Woodruff 2006, Olsen et al. 2015). Our present results show that, in addition to the decreased activin expression found in both models of lactotroph hyperplasia, an increased activin antagonism is also observed. Interestingly, this antagonism was found to be model specific.

In hCG $\beta+$ female pituitaries, the primary activinantagonism seems to be given by FST, as FST288 expression, mRNA and protein, were found increased compared to WTs, while no genotype difference was observed in males. However, decreased inhibin expression was observed in both the pituitary and the ovary, in this model.

The increase of FST expression observed in hCG $\beta+$ females could be due to the decreased levels of ovarian inhibins found in this group, as was described that inhibins inhibit pituitary FST mRNA levels (Bilezikjian et al. 1996, Dalkin et al. 1998).

Table 4 Activin inhibition of prolactin secretion in an ex vivo assay.

\begin{tabular}{|c|c|c|}
\hline \multirow[b]{2}{*}{ Time (minutes) } & \multicolumn{2}{|c|}{ WT } \\
\hline & Control & Act-A \\
\hline 15 & $221.12 \pm 21.13$ & $277.06 \pm 35.34$ \\
\hline 30 & $559.19 \pm 76.34$ & $383.80 \pm 92.86$ \\
\hline 45 & $1142.08 \pm 113.36$ & $681.16 \pm 124.65$ \\
\hline Fold increase & $5.16 \pm 0.01$ & $2.45 \pm 0.08$ \\
\hline
\end{tabular}

\begin{tabular}{ccc}
\hline \multicolumn{2}{c}{ hCG $\beta+$} \\
\hline Control & Act-A \\
\hline $520.81 \pm 18.09$ & & $612.77 \pm 1.48$ \\
$1014.91 \pm 3.88$ & & $724.32 \pm 42.41$ \\
$1950.12 \pm 22.57$ & $1350.41 \pm 114.98$ \\
$3.75 \pm 0.05$ & $2.20 \pm 0.11$ \\
\hline
\end{tabular}

Pituitaries from 6-month=old WT and hCG $\beta+$ female mice were incubated in serum free medium (Control group) or medium containing with 20 ng/mL human recombinant Activin A (Act-A group). Medium samples were taken at 15, 30, and 45 min. Prolactin levels released at the medium were assayed by RIA. Data show secreted PRL (ng/mL/mg protein). Fold increase: Released PRL at $45 \mathrm{~min} /$ released PRL at $15 \mathrm{~min}$ ) in each group. 


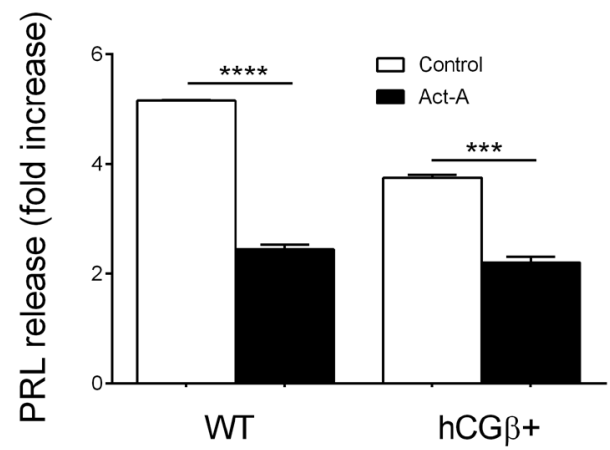

\section{Figure 10}

Inhibition of prolactin secretion by activin in an ex vivo assay. Fold increase in PRL release (45 min/15 min, data from Table 4) in each group. Data analyzed by two-way ANOVA (genotype $\times$ treatment), followed by a Šídák post hoc analysis. Interaction $P=0.0039$. $* \star \star \star P<0.0001$ WT control vs WT Act-A; $* * * P=0.0007$ hCG $\beta+$ control vs hCG $\beta+$ Act-A. Data are expressed as mean \pm S.E.M. $n=3 /$ group.

In contrast, increased levels of pituitary and ovarian Inha were found in Drd2KO females compared to WTs, suggesting that both local and gonadal inhibins mediate activin antagonism in this mouse model.

The differences observed in Inha expression among sexes and genotypes in both models, and in particular, among hCG $\beta$ and Drd 2 female mice, could be related to the differences found in serum FSH levels, as was previously demonstrated (Woodruff et al. 1996).

Due to the high hCG circulating levels (Rulli et al. 2002, Ratner et al. 2012), hCG $\beta+$ females present high levels of estradiol, testosterone, and progesterone during their sexual development. From 2 months of age serum prolactin levels increase and females present lactotroph hyperplasia followed by the development of prolactinomas, probably due to the over-exposure to estrogens during peripuberty. At 6 months, hCG $\beta+$-female
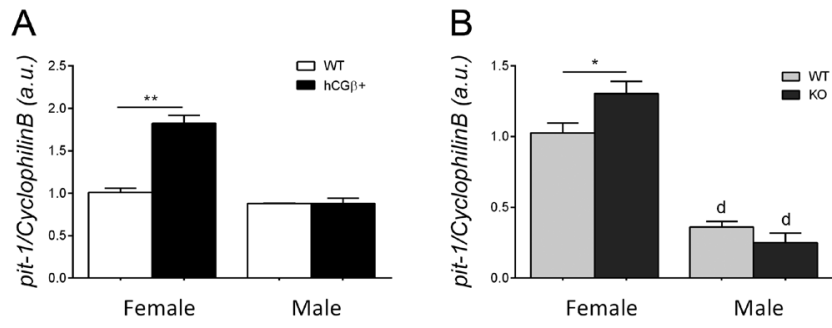

\section{Figure 11}

Pituitary mRNA expression of Pit-1 in 6-month-old hCG $\beta$ and 8-month-old Drd2 mice. mRNA transcripts were amplified with specific primers by qRT-PCR and normalized to CyclophilinB. Results are expressed relative to those for WT females. Data were analyzed by two-way ANOVA (sex $\times$ genotype), followed by a Tukey's post hoc analysis when the interaction effect was significant. Data are expressed as mean \pm S.E.M. $n=6$-8/group. (A) hCG $\beta$ mice. Interaction $P=0.0224$. ** $P<0.01 \mathrm{hCG} \beta+$ vs WT female. (B) Drd2 mice. Interaction $P=0.0463$. ${ }^{*} P<0.05$ KO vs WT female. ${ }^{d} p<0.01$ male vs female. ovaries present massive luteinization with persistently elevated levels of androgens. This hormonal environment induces a significant decrease in GnRH as well as FSH secretion (Rulli \& Huhtaniemi 2005), with concomitant decrease in ovarian and pituitary inhibin production (McLachlan et al. 1989, Smith et al. 1991, Shayya et al. 2014). In the same way, the reduced Inha expression found in hCG $\beta+$ male mice pituitaries could be explained by the decreased FSH production and the abnormal development of reproductive organs characteristic of this genotype (Rulli et al. 2003, Gonzalez et al. 2011) as previously proposed by Dias et al. (2009).

In contrast, serum FSH levels remain higher in female mice lacking Drd2 receptors compared to WTs. This fact could be related to the hypoestrogenism presented in Drd2KO females compared to WTs (Saiardi et al. 1997). The higher FSH levels could explain the increased expression of pituitary and gonadal inhibins in this animal model.

On the other hand, the lower serum LH levels observed in both, hCG $\beta+$ and Drd2KO females, could be related to the hyperprolactinemia observed in these groups that induces a significant decrease in GnRH secretion that impacts on LH levels (Rulli \& Huhtaniemi 2005).

Inhibins antagonize activin signalling by competitive binding to ActRII receptors (Vale et al. 2004). However, inhibins binding to ActRII shows 10-fold lower affinity than activins. Then, it was demonstrated that this antagonism requires the presence of a co-receptor betaglycan (also known as TGF $\beta$ type III receptor) which markedly increases the affinity of inhibins for ActRII (Lewis et al. 2000, Bernard et al. 2002).

When the pituitary betaglycan expression was explored, in our mouse models, it was found reduced in hCG $\beta+$ and KO female mice pituitaries, despite the levels of Inha observed in each model. This fact could limit the inhibin antagonism in the hyperplastic pituitaries. However, although betaglycan is expressed in almost all anterior pituitary cell types, the degree of expression is celltype specific. While 97\% of FSH-positive gonadotrophs are immune positive for betaglycan, only 23\% of lactotrophs are positive cells (MacConell et al. 2002). This finding suggests that betaglycan is mainly involved in the control of gonadotroph population. Nevertheless, further studies are needed to assess the impact of this reduced betaglycan expression on activin antagonism, not only in gonadotrophs but also in lactotrophs.

Other components involved in the regulation of activin function are the activin membrane receptors and its intracellular effectors (Suszko \& Woodruff 2006). 

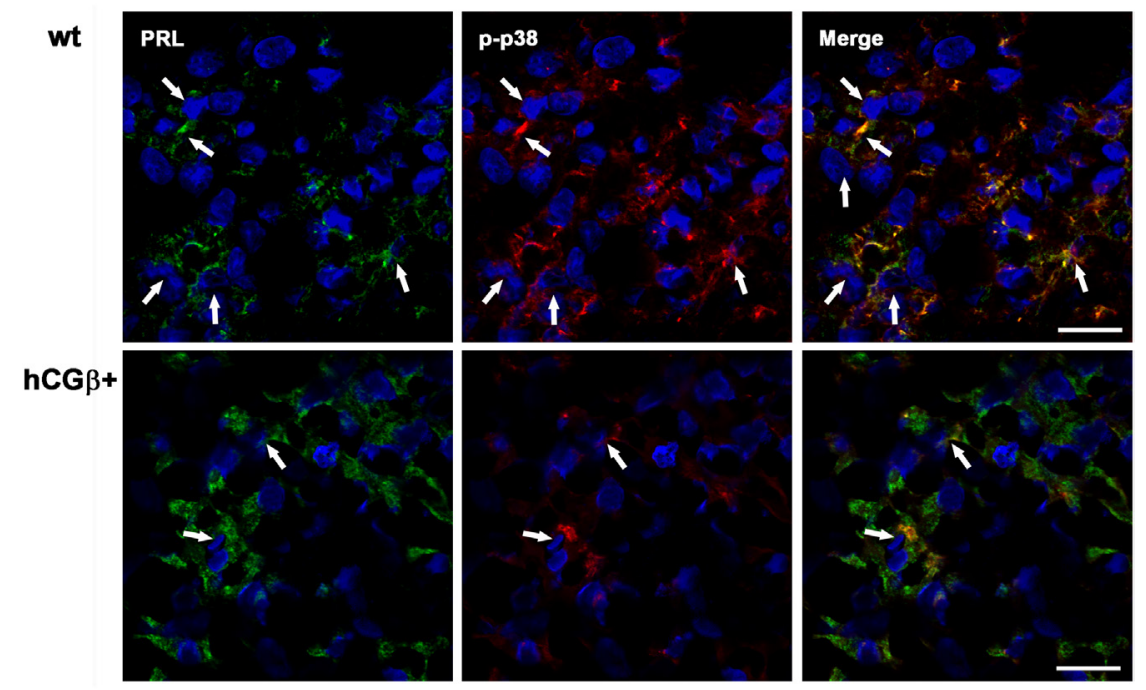

\section{Figure 12}

Phospho-p38MAPK (p-p38) expression in lactotrophs from hCG $\beta$ female mice pituitaries. Upper panel: wild type pituitary; Lower panel: hCG $\beta+$ mice pituitary. White arrows show lactotrophs (PRL+) expressing p-p38. Nuclei were immunostained with DAPI. Scale bar $=20 \mu \mathrm{m}$.

Activin receptor type IB (ActRIB or ALK4) has been involved in the inhibition of PRL synthesis and secretion (Lebrun et al. 1999, Miyamoto et al. 1999, Olsen et al. 2015).

In the present work, we found reduced ActRIB and ActRII mRNA expression in hCG $\beta+$ and Drd2KO female pituitaries (lactotroph hyperplasia) compared to WT counterparts. Additionally, we demonstrated, by double immunostaining, that ActRIB expression is present not only in gonadotrophs but also in lactotroph population in our experimental models, and that ActRIB remains expressed in lactotrophs from tumoural pituitaries. However, hyperplastic pituitaries (hCG $\beta+$ female) present a lower proportion of lactotrophs expressing ActRIB/ total lactotrophs compared to WTs. Moreover, in an ex vivo assay, we demonstrated that the inhibitory activin action on prolactin secretion is reduced in hyperplastic pituitaries compared to WT tissues.

Finally, and regarding the signalling involved, although the phosphorylation of SMAD2/3 proteins represent the canonical pathway, other intracellular effectors were also described to mediate activin actions, in a cell- and tissue-specific manner (Derynck \& Zhang 2003). In fact, in lactotrophs, activins inhibit prolactin gene expression through repression of the transcription factor Pit-1 (Lacerte et al. 2004) involving the p38MAPK pathway, in a Smad-independent manner (de Guise et al. 2006). Our present results show that the strong expression of p-p38 observed in lactotroph population from female WT pituitaries is significantly reduced in tumoural pituitaries concomitant with the decrease in the inhibitory activin action, the increase in Pit-1 expression and the lactotroph hyperplasia development.
Summarizing, the present results suggest that decreased pituitary activin function is involved in the lactotroph hyperplasia development. Moreover, our work also suggests that the gender differences observed in the pituitary activin-inhibin system, in the two mice models studied, could be related to the gender differences in the appearance of prolactinomas.

Prolactinomas are the pituitary tumours with higher prevalence in humans. Even though, they generally respond well to the current therapy with dopamine agonists, a subset of patients exhibit resistance to dopaminergic drugs. Then, alternative therapies are desired.

The present work highlights the importance of the activin inhibitory action on lactotroph function and places the local activin system as new targets in the treatment of dopamine agonist resistant prolactinomas.

\section{Declaration of interest}

The authors declare that there is no conflict of interest that could be perceived as prejudicing the impartiality of the research reported.

\section{Funding}

This work was supported by the Agencia Nacional de Promoción Científica y Técnica, Buenos Aires, Argentina (grant PICT 2016 N0252 to G D T; grant PICT 2017 N0072 to G D T), René Barón Foundation (to G D T and S B R), Williams Foundation (to G D T and S B R).

\section{Acknowledgments}

The prolactin RIA kit was generously provided by the National Institute of Diabetes and Digestive and Kidney Diseases National Hormone and Pituitary Program (Dr Parlow). 


\section{References}

Asa SL, Kelly MA, Grandy DK \& Low MJ 1999 Pituitary lactotroph adenomas develop after prolonged lactotroph hyperplasia in dopamine D2 receptor-deficient mice. Endocrinology 140 5348-5355. (https://doi.org/10.1210/endo.140.11.7118)

Bernard DJ, Chapman SC \& Woodruff TK 2002 Inhibin binding protein (InhBP/p120), betaglycan, and the continuing search for the inhibin receptor. Molecular Endocrinology 16 207-212. (https://doi. org/10.1210/mend.16.2.0783)

Bilezikjian LM, Corrigan AZ, Blount AL \& Vale WW 1996 Pituitary follistatin and inhibin subunit messenger ribonucleic acid levels are differentially regulated by local and hormonal factors. Endocrinology 137 4277-4284. (https://doi.org/10.1210/endo.137.10.8828487)

Bilezikjian LM, Blount AL, Leal AMO, Donaldson CJ, Fischer WH \& Vale WW 2004 Autocrine/paracrine regulation of pituitary function by activin, inhibin and follistatin. Molecular and Cellular Endocrinology 225 29-36. (https://doi.org/10.1016/j.mce.2004.02.010)

Bilezikjian LM, Justice NJ, Blackler AN, Wiater E \& Vale WW 2012 Celltype specific modulation of pituitary cells by activin, inhibin and follistatin. Molecular and Cellular Endocrinology 359 43-52. (https:// doi.org/10.1016/j.mce.2012.01.025)

Ciccarelli A, Daly AF \& Beckers A 2005 The epidemiology of prolactinomas. Pituitary 8 3-6. (https://doi.org/10.1007/s11102-0055079-0)

Colao A \& Savastano S 2011 Medical treatment of prolactinomas. Nature Reviews: Endocrinology 7 267-278. (https://doi.org/10.1038/ nrendo.2011.37)

Colao A, Sarno AD, Cappabianca P, Briganti F, Pivonello R, Somma CD, Faggiano A, Biondi B \& Lombardi G 2003 Gender differences in the prevalence, clinical features and response to cabergoline in hyperprolactinemia. European Journal of Endocrinology 148 325-331. (https://doi.org/10.1530/eje.0.1480325)

Dalkin AC, Haisenleder DJ, Gilrain JT, Aylor K, Yasin M \& Marshall JC 1998 Regulation of pituitary follistatin and inhibin/activin subunit messenger ribonucleic acids (mRNAs) in male and female rats: evidence for inhibin regulation of follistatin mRNA in females. Endocrinology 139 2818-2823. (https://doi.org/10.1210/ endo.139.6.6057)

Davis JR, Farrell WE \& Clayton RN 2001 Pituitary tumours. Reproduction 121 363-371. (https://doi.org/10.1530/rep.0.1210363)

de Guise C, Lacerte A, Rafiei S, Reynaud R, Roy M, Brue T \& Lebrun JJ 2006 Activin inhibits the human Pit-1 gene promoter through the p38 kinase pathway in a Smad-independent manner. Endocrinology 147 4351-4362. (https://doi.org/10.1210/en.2006-0444)

Derynck R \& Zhang YE 2003 Smad-dependent and Smad-independent pathways in TGF- $\beta$ family signalling. Nature 425 577-584. (https:// doi.org/10.1038/nature02006)

Dias VL, Rajpert-De Meyts E, McLachlan R \& Loveland KL 2009 Analysis of activin/TGFB-signaling modulators within the normal and dysfunctional adult human testis reveals evidence of altered signaling capacity in a subset of seminomas. Reproduction 138 801-811. (https://doi.org/10.1530/REP-09-0206)

Díaz-Torga G, Feierstein C, Libertun C, Gelman D, Kelly MA, Low MJ, Rubinstein M \& Becú-Villalobos D 2002 Disruption of the D2 dopamine receptor alters GH and IGF-I secretion and causes dwarfism in male mice. Endocrinology 143 1270-1279. (https://doi.org/10.1210/ endo.143.4.8750)

Engel ME, McDonnell MA, Law BK \& Moses HL 1999 Interdependent SMAD and JNK signaling in transforming growth factor- $\beta$-mediated transcription. Journal of Biological Chemistry 274 37413-37420. (https://doi.org/10.1074/jbc.274.52.37413)

Fainstein Day P, Glerean M, Lovazzano S, Pietrani M, Christiansen S, Balzaretti M, Kozak A \& Carrizo A 2010 Gender differences in macroprolactinomas: study of clinical features, outcome of patients and Ki-67 expression in tumor tissue. Frontiers of Hormone Research 38 50-58. (https://doi.org/10.1159/000318494)

Faraoni EY, Camilletti MA, Abeledo-Machado A, Ratner LD, de Fino F, Ipo Huhtaniemi I, Rulli SB \& Díaz-Torga G 2017 Sex differences in the development of prolactinoma in mice overexpressing hCGB: role of TGFB1. Journal of Endocrinology 232 535-546. (https://doi. org/10.1530/JOE-16-0371)

Farrell WE 2006 Pituitary tumours: findings from whole genome analyses. Endocrine-Related Cancer 13 707-716. (https://doi.org/10.1677/ erc.1.01131)

Gillam MP, Molitch ME, Lombardi G \& Colao A 2006 Advances in the treatment of prolactinomas. Endocrine Reviews 27 485-534. (https:// doi.org/10.1210/er.2005-9998)

Gonzalez B, Ratner LD, Di NP, Poutanen M, Huhtaniemi IT, Calandra RS, Lux-Lantos VAR \& Rulli SB 2011 Endogenously elevated androgens alter the developmental programming of the hypothalamic-pituitary axis in male mice. Molecular and Cellular Endocrinology 332 78-87. (https://doi.org/10.1016/j.mce.2010.09.016)

Gregory SJ \& Kaiser UB 2004 Regulation of gonadotropins by inhibin and activin. Seminars in Reproductive Medicine 22 253-267. (https://doi. org/10.1055/s-2004-831901)

Kars M, Dekkers OM, Pereira AM \& Romijn JA 2010 Update in prolactinomas. Netherlands Journal of Medicine 68 104-112.

Kelly MA, Rubinstein M, Asa SL, Zhang G, Saez C, Bunzow JR, Allen RG, Hnasko R, Ben-Jonathan N, Grandy DK, et al. 1997 Pituitary lactotroph hyperplasia and chronic hyperprolactinemia in dopamine D2 receptor-deficient mice. Neuron 19 103-113. (https://doi. org/10.1016/s0896-6273(00)80351-7)

Keogh EJ, Lee VW, Rennie GC, Burger HG, Hudson B \& De Kretser DM 1976 Selective suppression of FSH by testicular extracts. Endocrinology 98 997-1004. (https://doi.org/10.1210/endo-98-4-997)

Kovacs K, Horvath E \& Vidal S 2001 Classification of pituitary adenomas. Journal of Neuro-Oncology 54 121-127. (https://doi. org/10.1023/a:1012945129981)

Lacerte A, Lee EH, Reynaud R, Canaff L, De Guise C, Devost D, Ali S, Hendy GN \& Lebrun JJ 2004 Activin inhibits pituitary prolactin expression and cell growth through Smads, Pit-1 and menin. Molecular Endocrinology 18 1558-1569. (https://doi.org/10.1210/ me.2003-0470)

Lebrun JJ 2009 Activin, TGF-beta and menin in pituitary tumorigenesis. Advances in Experimental Medicine and Biology 668 69-78. (https://doi. org/10.1007/978-1-4419-1664-8_7)

Lebrun JJ, Takabe K, Chen Y \& Vale W 1999 Roles of pathway-specific and inhibitory Smads in activin receptor signaling. Molecular Endocrinology 13 15-23. (https://doi.org/10.1210/mend.13.1.0218)

Lerch TF, Shimasaki S, Woodruff TK \& Jardetzky TS 2007 Structural and biophysical coupling of heparin and activin binding to follistatin isoform functions. Journal of Biological Chemistry 282 15930-15939. (https://doi.org/10.1074/jbc.M700737200)

Lewis KA, Gray PC, Blount AL, MacConell LA, Wiater E, Bilezikjian LM \& Vale W 2000 Betaglycan binds inhibin and can mediate functional antagonism of activin signalling. Nature $\mathbf{4 0 4} 411-414$. (https://doi. org/10.1038/35006129)

Liu JK \& Couldwell WT 2004 Contemporary management of prolactinomas. Neurosurgical Focus 16 E2. (https://doi.org/10.3171/ foc.2004.16.4.3)

MacConell LA, Leal AMO \& Vale WW 2002 The distribution of betaglycan protein and mRNA in rat brain, pituitary, and gonads: implications for a role for betaglycan in inhibin-mediated reproductive functions. Endocrinology 143 1066-1075. (https://doi. org/10.1210/endo.143.3.8707)

Maiter D 2019 Management of dopamine agonist-resistant prolactinoma. Neuroendocrinology 109 42-50. (https://doi. org/10.1159/000495775)

Makanji Y, Zhu J, Mishra R, Holmquist C, Wong WPS, Schwartz NB, Mayo KE \& Woodruff TK 2014 Inhibin at 90: from discovery to https://joe.bioscientifica.com

https://doi.org/10.1530/JOE-19-0326 (c) 2020 Society for Endocrinology Published by Bioscientifica Ltd. Printed in Great Britain 
clinical application, a historical review. Endocrine Reviews 35 747-794 (https://doi.org/10.1210/er.2014-1003)

McLachlan RI, Cohen NL, Vale WW, Rivier JE, Burger HG, Bremner WJ \& Soules MR 1989 The importance of luteinizing hormone in the control of inhibin and progesterone secretion by the human corpus luteum. Journal of Clinical Endocrinology and Metabolism 68 1078-1085. (https://doi.org/10.1210/jcem-68-6-1078)

Mete O, Cintosun A, Pressman I \& Asa SL 2018 Epidemiology and biomarker profile of pituitary adenohypophysial tumors. Modern Pathology 31 900-909 (https://doi.org/10.1038/s41379-018-0016-8)

Mindermann T \& Wilson CB 1994 Age-related and gender-related occurrence of pituitary adenomas. Clinical Endocrinology 41 359-364. (https://doi.org/10.1111/j.1365-2265.1994.tb02557.x)

Miyamoto S, Irahara M, Ushigoe K, Kuwahara A, Sugino H \& Aono T 1999 Effects of activin on hormone secretion by single female rat pituitary cells: analysis by cell immunoblot assay. Journal of Endocrinology 161 375-382. (https://doi.org/10.1677/joe.0.1610375)

Molitch ME 2014 Management of medically refractory prolactinoma. Journal of Neuro-Oncology 117 421-428. (https://doi.org/10.1007/ s11060-013-1270-8)

Namwanje M \& Brown CW 2016 Activins and inhibins: roles in development, physiology, and disease. Cold Spring Harbor Perspectives in Biology 8 a021881. (https://doi.org/10.1101/cshperspect.a021881)

Olsen OE, Wader KF, Hella H, Mylin AK, Turesson I, Nesthus I, Waage A, Sundan A \& Holien T 2015 Activin A inhibits BMP-signaling by binding ACVR2A and ACVR2B. Cell Communication and Signaling 13 27. (https://doi.org/10.1186/s12964-015-0104-z)

Perez PA, Petiti JP, Picech F, Guido CB, dV Sosa L, Grondona E, Mukdsi JH, De Paul AL, Torres AI \& Gutierrez S 2018 Estrogen receptor beta regulates the tumoral suppressor PTEN to modulate pituitary cell growth. Journal of Cellular Physiology 233 1402-1413. (https://doi. org/10.1002/jcp.26025)

Primeau V, Raftopoulos C \& Maiter D 2012 Outcomes of transsphenoidal surgery in prolactinomas: improvement of hormonal control in dopamine agonist-resistant patients. European Journal of Endocrinology 166 779-786. (https://doi.org/10.1530/EJE-11-1000)

Ratner LD, Gonzalez B, Ahtiainen P, Di Giorgio NP, Poutanen M, Calandra RS, Huhtaniemi IT \& Rulli SB 2012 Short-term pharmacological suppression of the hyperprolactinemia of infertile hCG-overproducing female mice persistently restores their fertility. Endocrinology 153 5980-5992. (https://doi.org/10.1210/en.2012-1393)

Recouvreux MV, Guida MC, Rifkin DB, Becu-Villalobos D \& DiazTorga G 2011 Active and total transforming growth factor-beta1 are differentially regulated by dopamine and estradiol in the pituitary. Endocrinology 152 2722-2730. (https://doi.org/10.1210/en.2010-1464)

Risbridger GP, Schmitt JF \& Robertson DM 2001 Activins and inhibins in endocrine and other tumors. Endocrine Reviews 22 836-858. (https:// doi.org/10.1210/edrv.22.6.0450)

Rulli SB \& Huhtaniemi I 2005 What have gonadotrophin overexpressing transgenic mice taught us about gonadal function? Reproduction 130 283-291. (https://doi.org/10.1530/rep.1.00661)

Rulli SB, Kuorelahti A, Karaer O, Pelliniemi LJ, Poutanen M \& Huhtaniemi I 2002 Reproductive disturbances, pituitary lactotrope adenomas, and mammary gland tumors in transgenic female mice producing high levels of human chorionic gonadotropin. Endocrinology 143 4084-4095. (https://doi.org/10.1210/en.2002220490)

Rulli SB, Ahtiainen P, Makela S, Toppari J, Poutanen M \& Huhtaniemi I 2003 Elevated steroidogenesis, defective reproductive organs, and infertility in transgenic male mice overexpressing human chorionic gonadotropin. Endocrinology 144 4980-4990. (https://doi. org/10.1210/en.2003-0403)

Saiardi A, Bozzi Y, Baik JH \& Borrelli E 1997 Antiproliferative role of dopamine: loss of D2 receptors causes hormonal dysfunction and pituitary hyperplasia. Neuron 19 115-126. (https://doi.org/10.1016/ S0896-6273(00)80352-9)
Schlechte JA 2007 Long-term management of prolactinomas. Journal of Clinical Endocrinology and Metabolism 92 2861-2865. (https://doi. org/10.1210/jc.2007-0836)

Schneyer AL, Wang Q, Sidis Y \& Sluss PM 2004 Differential distribution of follistatin isoforms: application of a new FS315-specific immunoassay. Journal of Clinical Endocrinology and Metabolism 89 5067-5075. (https://doi.org/10.1210/jc.2004-0162)

Shayya RF, Rosencrantz MA, Chuan SS, Cook-Andersen H, Roudebush WE, Irene Su H, Shimasaki S \& Chang RJ 2014 Decreased inhibin B responses following recombinant human chorionic gonadotropin administration in normal women and women with polycystic ovary syndrome. Fertility and Sterility 101 275-279. (https://doi.org/10.1016/j.fertnstert.2013.09.037)

Shi L, Resaul J, Owen S, Ye L \& Jiang WG 2016 Clinical and therapeutic implications of follistatin in solid tumours. Cancer Genomics and Proteomics 13 425-435. (https://doi.org/10.21873/cgp.20005)

Shimasaki S, Koga M, Esch F, Mercado M, Cooksey K, Koba A \& Ling N 1988 Porcine follistatin gene structure supports two forms of mature follistatin produced by alternative splicing. Biochemical and Biophysical Research Communications 152 717-723. (https://doi.org/10.1016/ s0006-291x(88)80097-4)

Smith KB, Millar MR, McNeilly AS, Illingworth PJ, Fraser HM \& Baird DT 1991 Immunocytochemical localization of inhibin alpha-subunit in the human corpus luteum. Journal of Endocrinology 129 155-160. (https://doi.org/10.1677/joe.0.1290155)

Smith TR, Hulou MM, Huang KT, Gokoglu A, Cote DJ, Woodmansee WW \& Laws ERJ 2015 Current indications for the surgical treatment of prolactinomas. Journal of Clinical Neuroscience 22 1785-1791. (https:// doi.org/10.1016/j.jocn.2015.06.001)

Sugino H, Sugino K, Hashimoto O, Shoji H \& Nakamura T 1997 Follistatin and its role as an activin-binding protein. Journal of Medical Investigation 44 1-14.

Suszko MI \& Woodruff TK 2006 Cell-specificity of transforming growth factor-beta response is dictated by receptor bioavailability. Journal of Molecular Endocrinology 36 591-600. (https://doi.org/10.1677/ jme.1.01936)

Szeto DP, Ryan AK, O'Connell SM \& Rosenfeld MG 1996 P-OTX: a PIT-1interacting homeodomain factor expressed during anterior pituitary gland development. PNAS 93 7706-7710. (https://doi.org/10.1073/ pnas.93.15.7706)

Thompson TB, Lerch TF, Cook RW, Woodruff TK \& Jardetzky TS 2005 The structure of the follistatin:activin complex reveals antagonism of both type I and type II receptor binding. Developmental Cell $9535-543$. (https://doi.org/10.1016/j.devcel.2005.09.008)

Vale W, Rivier J, Vaughan J, McClintock R, Corrigan A, Woo W, Karr D \& Spiess J 1986 Purification and characterization of an FSH releasing protein from porcine ovarian follicular fluid. Nature 321 776-779. (https://doi.org/10.1038/321776a0)

Vale W, Wiater E, Gray P, Harrison C, Bilezikjian L \& Choe S 2004 Activins and inhibins and their signaling. Annals of the New York Academy of Sciences 1038 142-147. (https://doi.org/10.1196/annals.1315.023)

Vroonen L, Jaffrain-Rea ML, Petrossians P, Tamagno G, Chanson P, Vilar L, Borson-Chazot F, Naves LA, Brue T, Gatta B, et al. 2012 Prolactinomas resistant to standard doses of cabergoline: a multicenter study of 92 patients. European Journal of Endocrinology 167 651-662. (https://doi.org/10.1530/EJE-12-0236)

Welt C, Sidis Y, Keutmann H \& Schneyer A 2002 Activins, inhibins, and follistatins: from endocrinology to signaling. A paradigm for the new millennium. Experimental Biology and Medicine 227 724-752. (https:// doi.org/10.1177/153537020222700905)

Wiater E, Lewis KA, Donaldson C, Vaughan J, Bilezikjian L \& Vale W 2009 Endogenous betaglycan is essential for high-potency inhibin antagonism in gonadotropes. Molecular Endocrinology 23 1033-1042. (https://doi.org/10.1210/me.2009-0021)

Wong A, Eloy JA, Couldwell WT \& Liu JK 2015a Update on prolactinomas. Part 1: clinical manifestations and diagnostic 
challenges. Journal of Clinical Neuroscience 22 1562-1567. (https://doi. org/10.1016/j.jocn.2015.03.058)

Wong A, Eloy JA, Couldwell WT \& Liu JK 2015b Update on

prolactinomas. Part 2: treatment and management strategies. Journal of Clinical Neuroscience 22 1568-1574. (https://doi.org/10.1016/j. jocn.2015.03.059)
Woodruff TK, Besecke LM, Groome N, Draper LB, Schwartz NB \& Weiss J 1996 Inhibin A and inhibin B are inversely correlated to folliclestimulating hormone, yet are discordant during the follicular phase of the rat estrous cycle, and inhibin A is expressed in a sexually dimorphic manner. Endocrinology 137 5463-5467. (https://doi. org/10.1210/endo.137.12.8940372)

Received in final form 6 December 2019

Accepted 16 December 2019

Accepted Manuscript published online 17 December 2019
(C) 2020 Society for Endocrinology Published by Bioscientifica Ltd.
Printed in Great Britain 